\title{
The Correlation Between Knowledge Level and Perception with the Community Stigma on PLWH in Pandowoharjo Village, Sleman
}

\author{
Aunana Finnajakh*, Niken Meilani, Nanik Setiyawati \\ Department of Midwifery Polytechnic Ministry of Health Yogyakarta \\ Email*: Finna241996@yahoo.co.id
}

\begin{abstract}
From the number of years HIV / AIDS cases are increasing. In Indonesia, the number of people living with HIV in 2016 was $620,000(530,000-730,000)$. Yogyakarta Special Region (DIY) in 2017 was the $12^{\text {th }}$ rank as the province with the most HIV-AIDS patients in Indonesia. Sleman Regency was the regency with the highest HIV / AIDS patients in DIY. Stigma causes HIV prevention and health services to be less effective.
\end{abstract}

Keywords: level of knowledge, perception, PLWH, stigma

\section{INTRODUCTION}

From year to year, the number of HIV / AIDS cases is increasing. The United Nations Program on HIV / AIDS has reported a number of people living with HIV of 36.7 million (30.8 -42.9 million), adults ( $\geq 15$ years) of 34.5 million (28.8-40.2 million), women> 15 years 17.8 million (15.4-20.3 million), children ( $<15$ years) of 2.1 (1.7-2.6 million) while new HIV positive cases in the year 2016 increased to 1.8 million (1.6-2.1 million) and the number of people died of AIDS in 2016 was 1 million people (830,000-1.2 million). The number of people living with HIV who realized their status of being infected with HIV in Indonesia in 2016 was 620,000 $(530,000-730,000)^{(1)}$

The number of new HIV positive cases reported in 2017 according to the Ministry of Health of the Republic of Indonesia in 2017 was 48,300 million more than a year earlier, that were 41,250 million HIV populations in 2016. The number of new AIDS cases was relatively stable. The percentage of new HIV positive cases in women was $36.7 \%$ and men $63.3 \%$. The percentage of AIDS cases in women was $31.5 \%$, men $67.9 \%$ and the percentage who did not report sex was $0.6 \%$.(2)

Based on the highest number of HIV infections reported by the province until December 2017 and according to the Ministry of Health of the Republic of Indonesia in 2017 was in Jakarta with 51,981 cases. The highest number of AIDS was in Papua with 19,729 cases. DIY ranked $12^{\text {th }}$ as the province with the most people with HIV-AIDS infection.

The highest HIV / AIDS cases based on districts/cities that occurred in DIY in 2017 were located in Sleman Regency with 915 people infected with HIV. The rise of HIV / AIDS cases required the government to carry out various targeted programs until 2019. The AIDS Commission (2015) said that in Indonesia there were several targets to be achieved in 2015-2019 namely reducing the number of new infections by $50 \%$ from the projection in 2014. If there were no interventions, at least $40 \%$ of PLWH knew HIV status, reducing deaths from AIDS by $50 \%$ and others. The HIV prevention strategy carried out in Indonesia for the 2015-2019 period was to create an enabling environment for key populations and PLWH ${ }^{(2-4)}$

The strategy seemed unsuccessful because the stigma and discrimination in Indonesia were still high. This caused HIV prevention and health services to be less effective. PLWH and key populations fear discrimination, they will be reluctant to take HIV testing, including accessing HIV health services. The results of the study conducted by Francis, et al. (2018) Uganda, Africa stated that one of the factors that inhibited access, availability and utilization of HIV testing and care services was the HIV Stigma. This is also supported by the results of a study conducted by Gertrude, et al. (2013) conducted in African Uganda saying that one of the obstacles in free HIV care services to HIV-positive patients is the fear of stigma and disclosure of HIV status. On the other hand, a study conducted by Carmen, et al. (2017) conducted in Canada showed that the stigma associated with HIV was related ( $p<0.05$ ) to the level of compliance of PLWHA in consuming ARV drugs. Stigma makes PLHIV not optimal in taking ARV drugs. Research conducted by Burhan R (2013) states that there is a statistically significant correlation, namely the stigma of the community towards PLWHA with the use of health facilities by women infected with HIV / AIDS. The results of these studies prove that the existence of stigma greatly affects the access, availability and utilization of testing services, HIV care and also the compliance of PLWHA in consuming ARV. ${ }^{(4-8)}$

Stigma is an attribute, behaviour or social reputation that discredits in a certain way. Stigma arises because 
seeing HIV-AIDS can occur in groups that have different behaviours with most people. Stigma has two perspectives, namely community stigma and self-stigma. Community stigma occurs when the general public agrees with a person's bad stereotypes (eg, mental illness, addicts, etc.) and self-stigma is a consequence of stigmatized people applying stigma to themselves. The application of stigma in the community like PLWHA is still often rejected and expelled from family and community. The right to education and the right to work for PLWHA is still often denied. $(4,9)$

The stigma according to the United Nations Program on HIV / AIDS (2017) has occurred in more than 65 countries that stigmatize PLWH. The form of stigma given is, for example, $>50 \%$ of men and women aged 15-49 years reported that they did not buy vegetables from sellers with the status of PLWH that had occurred between 2009-2014. In 22 countries including > 10\% PLWH were denied for medical care, were refused to apply for jobs because of their HIV status and in 30 countries including being fired from their jobs because of their HIV status. ${ }^{(1)}$

The United Nations Program on HIV / AIDS (2017) has recorded the prevalence of stigma in third place in the Asia Pacific region and Indonesia occupying the highest position at $62.8 \%$. The high prevalence of stigma in HIV is possible for many factors that influence it such as low knowledge about HIV, high negative perceptions of HIV, sex and others. ${ }^{(1)}$

The stigma against PLWH is reflected in social behaviour that discredits in certain ways towards PLWH. The results of the study by Zahroh, et al. (2015) showed that there was a correlation ( $\mathrm{p}$-value $<0.05$ ) between HIV / AIDS knowledge, gender and the perception of stigma against HIV-positive children. Subsequent research was conducted by Aeree Sohn and Sungbok Park (2012) in Korea which showed that the low level of knowledge about HIV / AIDS among Korean adolescents affected the high level of attitudes towards HIV-infected people.

The study is similar to a research conducted by Louise Balfour (2010) which was carried out in South America. The result showed that students who had received education training about HIV/AIDS had higher knowledge than those who had not received education training. Low-level of HIV stigma was relatively supported, and those who had higher knowledge had a greater influence on low-level of HIV stigma. ${ }^{(10-12)}$

According to a literature review conducted by Paruati, et al. (2012), the factors influencing the emergence of stigma and discrimination on PLWH (People Living With HIV/AIDS) are Knowledge about HIV/AIDS and Perception about PLWHA. Similar result is also found in the research conducted by Rizka Sofia (2015) in her research which stated that the level of knowledge about HIV/AIDS with the stigma about PLWH obtained $p$-value $=0.03$ meaning that it was significant. It was in contrast to the research conducted by Ni'mal Baroyo (2017) which stated that the level of knowledge was not significant $(p>0.05)$ in predisposing factors on the attitude of stigma on PLWH. The research was in line with the research conducted by Hesty and Suherni (2015) which declared that there was no correlation between the level of knowledge and the stigma of students on PLWH. (13-15)

The other result of study suggests that there is a correlation between perceptions and students' stigma on PLWH. Another study conducted by Zahroh et al. (2014) conveyed that family attitudes and respondents' perceptions on PLWHA were influential factors in the emergence of stigma on PLWH. The research conducted by Berliana Situmeang, et al. (2017) stated that lack of knowledge about HIV/AIDS was associated with the stigma on PLWH. The next study conducted by Hermawati (2011) stated that there was a relationship between the perceptions of PLWH on the community's stigma of HIV/AIDS and social interaction on PLWH. (16-18)

From the results of several studies above, the related factors and the most dominant is the level of knowledge and perception of HIV/AIDS on PLWHA. Because of the stigma of HIV/AIDS in Indonesia that is still high, the researchers are interested in analyzing the Correlation between Knowledge Level and Perception with Community Stigma on PLWHA in Pandowoharjo Village, Sleman District, Sleman Regency.

\section{MATERIALS AND METHODS}

This research is a descriptive analytic study. This research was conducted using a quantitative approach with cross-sectional research design. ${ }^{(19)}$

The independent variable in this research is the level of knowledge and perception, while the dependent variable is the stigma of the community on PLWHA. The characteristics of subjects are the age, gender, occupational status, education status, religion, and last education status. The research was conducted in four hamlets, namely Saragan Hamlet, Mancasan Hamlet, Plalangan Hamlet, and Gawar Hamlet, Pandowoharjo Village, Sleman District, Sleman Regency starting from October 2018 to June 2019. The populations in this study were all communities in Pandowoharjo Village, Sleman District, Sleman Regency with a total of 16,000 inhabitants. The total sample was 150 respondents. Based on the Lemeshow formula

$$
n=\frac{\left\{z_{1-\alpha / 2} \sqrt{2 P(1-P)}+z_{1-\beta} \sqrt{P_{1}\left(1-P_{1}\right)+P_{2}\left(1-P_{2}\right)}\right\}^{2}}{\left(P_{1}-P_{2}\right)^{2}}
$$

The sampling technique in this research used a proportional sampling method. The inclusion criteria in this research were respondents willing to be observed which were detected from the PSP (Approval after Explanation), and the respondents within the age of 15- 
49 years old which were detected from the their Family Card. Meanwhile, the exclusion criteria in this research were respondents with physical illness or disorders (coronary heart, stroke, diabetes mellitus type 1, cancer, Parkinson, and etc.), as well as those with mental illness who were considered able to obstruct in understanding and/or filling the questionnaire. They were detected from Pandowoharjo Village cadres and their move of domicile from Pandowoharjo Village was detected from the chief of hamlet at Pandowoharjo Village, Sleman District, Sleman Regency.

In this research, the level of knowledge about HIV/AIDS was categorized into three categories, namely "good" if the percentage result of respondents' score was $>80 \%$, "adequate" if the percentage result of respondents" score was $60-80 \%$, and "poor" if the percentage result of respondents' score was $<60 \%$. The community perceptions on PLWH were categorized into two categories, namely "positive" if it was > median score because the data were not normally distributed, and negative if it was $\leq$ median score because the data were not normally distributed. The community stigma on PLWH was categorized into two, namely "Stigma" if it was $\leq$ median score because the data were not normally distributed, and "Non-stigma" if it was > median score because the data were not normally distributed. (20-21)

The analysis was carried out by using SPSS software version 24. The analysis was carried out through univariate and bivariate analysis. Univariate analysis was conducted to determine the distribution of respondents from each variable while bivariate analysis was conducted to determine the correlation between independent and dependent variables.

\section{RESULTS AND DISCUSSION}

Table 1. Characteristics of Respondents.

\begin{tabular}{|c|c|c|}
\hline Characteristics & Frequency & $\%$ \\
\hline \multicolumn{3}{|l|}{ Age (Old) } \\
\hline $15-25$ & 34 & 22.7 \\
\hline $26-45$ & 89 & 59.3 \\
\hline $46-49$ & 27 & 18.0 \\
\hline \multicolumn{3}{|l|}{ The Last Education } \\
\hline Elementary School & 4 & 2.7 \\
\hline Junior High School & 17 & 11.3 \\
\hline Senior High School & 101 & 67.3 \\
\hline College & 28 & 18.7 \\
\hline \multicolumn{3}{|l|}{ Religion } \\
\hline Islam & 148 & 98.7 \\
\hline Christian & 2 & 1.3 \\
\hline \multicolumn{3}{|l|}{ Gender } \\
\hline Male & 43 & 28.7 \\
\hline Female & 107 & 71.3 \\
\hline \multicolumn{3}{|l|}{ Occupation } \\
\hline Housewife & 52 & 34.7 \\
\hline Laborer & 19 & 12.7 \\
\hline Private Employee & 34 & 22.7 \\
\hline Entrepreneur & 19 & 12.7 \\
\hline Student & 18 & 12.0 \\
\hline Unemployment & 3 & 2.0 \\
\hline
\end{tabular}

This research was conducted in Pandowoharjo Village, Sleman District, Sleman Regency. The hamlet locations taken place in this study were Mancasan Hamlet, Gawar Hamlet, Plalangan Hamlet, and Saragan Hamlet. Those hamlets were chosen because they had higher population than other hamlets in Pandowoharjo Village.

The result of research showed that most characteristics of respondents based on the age were within an age range of 26-45 years (59.3\%). According to the last education, most respondents (101) had high school education background $(67.3 \%)$ respondents. Based on religion followed, most respondents were Muslims with a total of 148 respondents (98.7\%). Based on the gender, most respondents were female with a total of 107 respondents $(71.3 \%)$. In addition, based on the occupation, most of respondents worked as housewives with a total of 52 respondents $(34.7 \%)$.

Table 2. Level of Knowledge about HIV/AIDS, Perception and Stigma on PLWH.

\begin{tabular}{lll}
\hline Variable & Frequency & $\%$ \\
\hline Stigma & 95 & 63.3 \\
Stigma & 55 & 36.7 \\
Non-stigma & & \\
Knowledge Level & & \\
Good & 15 & 10.0 \\
Adequate & 46 & 30.7 \\
Poor & 89 & 59.3 \\
Perception & & \\
Negative & 75 & 50 \\
Positive & 75 & 50 \\
\hline Total & 150 & 100 \\
\hline
\end{tabular}

Based on the Table 2 above, the result of the research on the knowledge level about HIV/AIDS variable showed that most respondents (89) had the knowledge level about HIV/AIDS in the less adequate category $(59.3 \%)$. The result of the research on the people's perception on PLWH variable showed that both the positive category and the negative category had a balanced score of 75 (50\%). The result of the research on the people's stigma on PLWH variable showed that most respondents (95) gave stigma on PLWH (63.3\%).

Before the analysis was conducted, a data normality test had been conducted with the result showing that the data on the perception variable and stigma variable were not normally distributed.

Based on the Table 3 above, most respondents (69) gave negative perception and stigma (92.0\%) to PLWH. The result of the Chi-Square showed the significance level of $0.000 \quad(\mathrm{p}<0.05)$ meaning that there was a significant correlation between PLWH perception and stigma on HIV patients. 
Table 3. Bivariate Analysis Result

\begin{tabular}{|c|c|c|c|c|c|c|c|}
\hline \multirow{3}{*}{ Variable } & \multicolumn{4}{|c|}{ Stigma } & \multirow{2}{*}{\multicolumn{2}{|c|}{ Total }} & \multirow{3}{*}{ P-value } \\
\hline & \multicolumn{2}{|c|}{ Stigma } & \multicolumn{2}{|c|}{ Non-Stigma } & & & \\
\hline & $\mathbf{N}$ & $\%$ & $\mathbf{n}$ & $\%$ & $\mathbf{F}$ & $\%$ & \\
\hline $\begin{array}{l}\text { Knowledge } \\
\text { Level }\end{array}$ & & & & & & & \\
\hline Good & 8 & 53.3 & 7 & 46.7 & 15 & 100 & \\
\hline Adequate & 29 & 63.0 & 17 & 37.0 & 46 & 100 & 0.684 \\
\hline Poor & 58 & 65.2 & 31 & 34.8 & 89 & 100 & \\
\hline Perception & & & & & & & 0.000 \\
\hline Negative & 69 & 92.0 & 6 & 8.0 & 75 & 100 & \\
\hline Positive & 26 & 34.7 & 49 & 65.3 & 75 & 100 & \\
\hline Total & 95 & 63.3 & 55 & 36.7 & 150 & 100 & \\
\hline
\end{tabular}

The result of the analysis on the variable of knowledge about HIV/AIDS showed that most of the respondents (58) had poor knowledge about HIV/AIDS and gave stigma $(65.2 \%)$. The result of the Chi-Square test showed the significance level of $0.684(p>0.05)$ meaning that there was no significant correlation between knowledge level and the stigma on HIV patients.

The characteristics of the respondents based on the result of the research showed that most of them were 2645 years old (59.3), Muslim (98.7\%), and female $(71.3 \%)$, and they had senior high school education background $(67.3 \%)$, and worked as housewives $(34.7 \%)$. The result of the research showed that most respondents gave stigma on PLWH (63.3\%), had poor knowledge about HIV/AIDS (59.3), balanced perception 75 to PLWH both in the positive category and negative category $(50 \%)$.

The stigma on PLWH was reflected in the discrediting social behaviors with certain ways to PLWH. The knowledge level and perception were included in the predisposing factors in PRECEDEPROCEED Theory Model in the independent variable. In the theory of PRECEDE-PROCEED behavioral changes model developed by Lawrence Green, it is stated that healthy behaviors are affected by both individual and environmental factors. Based on the result of the 0.684 ( $p>0.05)$ Chi-Square test on the knowledge level variable, it can be concluded that there was no significant correlation between knowledge level of HIV/AIDS and people's stigma on PLWHA. The crosstabulation analysis result however, showed that the stigma on PLWH tended to occur more on the people 58 with poor knowledge level about HIV/AIDS (65.2\%) than on the people 8 with good knowledge level about HIV/AIDS $(53.3 \%)$ or on those 29 with adequate knowledge level about HIV/AIDS (63.\%). Related to that finding, the result of the research was inconsistent with the previous study stating that the good knowledge about HIV/AIDS can lower the people's stigma to
PLWHA. It is in line with the research conducted by Ni'mal Boroyo (2017) stating that knowledge level is not significant $(p>0.05)$ to PLWH stigma. According to result of the research conducted by Ulfa Nurullita (2012), knowledge level about HIV/AIDS is not significantly correlated with stigma and discriminative behaviors to PLWH (each p-value is 1.00 and 0.303 respectively). ${ }^{(15,22-23)}$

It is also stated in the research conducted by Hesty Widyasih (2015) that there is no correlation between knowledge level about HIV/AIDS and students' stigma to PLWH (p-value $=0.075$ ). The research conducted by Eunce Oumu in the United States of America also proved that there is no significant correlation between stigma related to HIV and knowledge about HIV/AIDS. Moreover, according to Green theory cited in Priyoto (2014), predisposing in this case is the knowledge level about HIV/AIDS which is a factor influencing individual's behavior reflected in stigma. It is not however, the only factor triggering low healthy behavior. Reinforcing factor also plays an important role in behavioral changes reflected in stigma. ${ }^{(18,24)}$

Reinforcing is a strengthening factor in this case because it can be reflected on the information obtained from the village cadres stating that not all public figures and cadres in Pandowoharjo village participated in every activity about HIV/AIDS who acted as the role model and gave great influence in the society. ${ }^{(25)}$

The no correlation between knowledge level about HIV/AIDS and the people's stigma on PLWH is supported with the research conducted by Caroline Kingori, et. al. (2017) in the United States of America stating that there is no significant correlation between HIV knowledge and stigma with the significance level of $\mathrm{p}=0.06(\mathrm{p}>0.05)$. Another research conducted by Agung Trianto (2015) also stated that there is no difference in the influence of HIV/AIDS education to teenagers' behavior $(p=0.577)$ in the prevention of HIV/AIDS. The research with similar result was also conducted by Zahroh, et. al. (2015) showing that the Chi-Square test result with the significance level of $p=0.386(p>0.05)$ indicated that there was no correlation between the knowledge about IMS and HIV/AIDS and the people's stigma on PLWHA. The research conducted by Hesti Widyasih (2015) also stated that knowledge will form a certain belief so that one will behave according to his/her belief. However, knowledge changes do not always cause behavioral changes. The higher one's knowledge and understanding about HIV/AIDS, the lower the irrational fear that can trigger the stigma on PLWHA one's get. Comprehensive knowledge about HIV/AIDS can lower or even eradicate the myth or false belief about HIV/AIDS which finally will lower or even eradicate the epidemics of HIV/AIDS related to stigma. (18,25-28)

The research conducted by Naura Nyblade et. al. (2009) also stated that one of the matters to fight stigma 
is conducting intervention that is focused on the policy level. The intervention that can be conducted is in the form of training on how to bury HIV-diagnosed corpse, training on the treatment if one's infected by HIV, training on how to treat people with HIV/AIDS, and the way it can infect others, etc. In 2018, a dead PLWHA (people with HIV/AIDS) was found in one of the villages in Pandowoharjo. However, based on the information from the village cadres, there was no villager participating in the burial of the corpse.

It proves that the stigma is still high $(63.6 \%)$ in Pandowoharjo village. However, nowadays the interventions focused on the policy level is not yet applied in Pandowoharjo village, Sleman sub-district, Sleman regency. Behavioral changes reflected in stigma is not easily achievable just with mere incomprehensive HIV/AIDS knowledge. (29)

The result of statistics calculation on the variable of people's perception on PLWHA showed that the p-value of the Chi-Square test was $\mathrm{p}=0.000$ meaning that there was a correlation between the respondents' perception and people's stigma on PLWH. The result of the research was consistent with the previous studies. The research conducted by Zahroh et. al. (2014) stated that the family's behavior and respondents' perception on PLWHA are the factors influential to the emergence of stigma on PLWH. That research was consistent with the studies previously conducted, stating that perception can influence the emergence of stigma by the teacher to the students with HIV-positive. ${ }^{(10,28)}$

The research conducted by Hermawati (2011) stated that there is a correlation between PLWH perception and the people's stigma on HIV/AIDS with the social interaction on PLWH. Parvati et. al (2013) in her research stated that one of the factors influencing stigma and discrimination on PLWH is the respondents' perception on PLWH.

A similar research conducted by Febrianti (2016) also stated that perception is significantly correlated with the high school students' stigma on PLWH $>$ In that research, it is also elaborated that perception has the cause and effect correlation with the stigma on PLWH. Negative perception on PLWH influences the heavy stigma on PLWH (2.071) meaning that the teenagers with negative perception have twice risks on having heavy stigma on PLWH. ${ }^{(13,17,30)}$

Other research conducted by Wei Ma, et. al. (2012) in China stated that the respondents' perception about PLWH is the factor encouraging man who is having sex with man to participate in the decreasing HIV program. A research conducted by Garumma T Feyissa in Ethiopia in 2012 revealed that perception about HIV/AIDS is the predictor of the stigma and discrimination toward PLWH. On the same year, in South Africa, Julia Louw, et. al. stated that factor that is resulting the decreasing of HIV on young men in South Africa is Stigma about HIV/AIDS and negative perception on HIV/AIDS. A research conducted by Seen Toth, et. al. (2016) in the US showed that the factor influencing stigma on HIV positive and negative population is significantly correlated $(\mathrm{p}<0.05)$ to respondents' perception on PLWH. (31-34)

There is a correlation between society's perception of PLWHA $(\mathrm{p}<0.05)$ based on this research which is in line to Lawrence Green theory which stated that there are three main factors influencing a behavior. One of the factors is predisposing factor which is reflected in perception. According to Sito Meiyanto (2015) perception is the process used by an individual to manage and interpret their sensory impression in order to give a meaning to an object. One of the factors influencing one's perception is experience. People of Pandowoharjo had an experience of finding an PLWH who died in Pandowoharjo in 2018. However, there were no people of Pandowoharjo attending the funeral. It showed the correctness of the statistics test result of crosstab. The result showed that society with greater negative perception (69) gave stigma on PLWH (92\%). (35)

In this research there was a correlation between perception and society's stigma on PLWH having $\mathrm{p}$ value $=0.000 \quad(\mathrm{p}<0.05)$. However, there was no correlation between the level of knowledge and society's stigma on PLWH having $\mathrm{p}$-value $=0.684(\mathrm{p}>0.05)$. Therefore, it can be concluded that predisposing factor reflected in perception, according to L Green theory, influenced the behavior changes. But, knowledge changes did not always influence behavior changes. Other factors are required in order to change one's behavior such as reinforcing factor and enabling factor.

\section{CONCLUSIONS}

Based on the result and discussion of the research entitled "correlation between knowledge level and perception with society's stigma of PLWH in Pandowoharjo, sub-district Sleman, district Sleman", it can be concluded that:

1. The respondents of this research were mostly 26-45 years old women, muslim, high school graduates, and housewives.

2. Most of Pandowoharjo people had stigma to PLWH probably caused by the low level of HIV/AIDS knowledge and the high level of negative perception to PLWH.

3. Level of knowledge about HIV/AIDS on most Pandowoharjo people was categorized in poor level.

4. Society's perception on PLWH in Pandowoharjo either negative or positive have an equal value.

5. There were no correlation between level knowledge of HIV/AIDS and society's stigma on PLWH in Pandowoharjo, Sleman sub-district, Sleman district.

6. There was a correlation between perception and stigma society about PLWH in Pandowoharjo, Sleman sub-district, Sleman district. 


\section{Suggestion}

1. To The Head of Sleman Health care

To the head of Sleaman health care, it is expected to give education and approach related to HIV/AIDS which can held on regular basis in Pandowoharjo, Sleman sub-district, Sleman district.

2. To The Head of Pandowoharjo Village

To the head of Pandowoharjo village, it is expected to encourage and motivate Pandowoharjo people to receive better information about HIV/AIDS particularly when there are HIV/AIDS counseling. By receiving information about HIV/AIDS, they are also expected to be able to apply that information especially when they encounter a person with HIV/AIDS. So that Pandowoharjo can be a model to other villages and gradually be able to help the problem of society's stigma on PLWH in Indonesia.

3. To The Other Researcher

To other researchers, it is expected to not just using cross-sectional design which cannot clearly explain cause-effect correlation to every variable. A research design which is able to explain the cause-effect correlation, for instance Kohort design, is required. Therefore, the cause-effect connection of society's stigma on PLWH phenomenon can be clearly explained.

\section{REFERENCES}

Baroya, N. Predictor of Stigma and Discrimination Attitude to Person Living with HIV and AIDS (PLHIV) In Jember District. 13 Nomor, (2017).

Berliana Situmeang, Syahrizal Syarif, R. M. Hubungan Pengetahuan HIV / AIDS dengan Stigma terhadap Orang dengan HIV / AIDS di Kalangan Remaja 15-19 Tahun di Indonesia (Analisis Data SDKI Tahun 2012) Relationship HIV / AIDS Knowledge related Stigma towards People Living with HIV / AIDS among Adole. 1, 35-43 (2017).

Bajunirwe, F. et al. Towards 90-90-90 Target: Factors Influencing Availability, Access, and Utilization of HIV Services-A Qualitative Study in 19 Ugandan Districts. Biomed Res. Int. 2018, 9619684 (2018).

(UNAIDS). United National on AIDS 2017. (2017).

DIY, D. K. Profil Kesehatan Provinsi di DI Yogyakarta Tahun 2017. (2017).
Hesty Widyasihl, S. Faktor.Faktor yang Mempengaruhi Stigma Mahasiswa Poltekkes Kemenkes Yogyakarta terhadap Orang Dengan HIV/AIDS (ODHA'). Biomass Chem Eng 49, (2015).

Hidayat, Aziz Alimul. Metode Penelitian Kebidanan dan Teknik Analisis Data. Salemba Medika: Jakarta. (2014)

Kingori, C., Adwoa Nkansah, M. \& Haile. Factors Associated with HIV Related Stigma among College Students in the Midwest. AIMS Public Heal. 4, 347-363 (2017).

Khomsan, Ali. Faisal A, Neti H, Nani S dan Oktarina. 2014. Tumbuh kembang dan Pola Asuh Anak. IPB Press, Bogor

Komisi Penanggulangan HIV AIDS. Strategi dan Rencana Aksi Nasional 2015-2019 Penanggulangan HIV dan AIDS di Indonesia. (2015).

Logie, C. H. et al. Pathways from HIV-related stigma to antiretroviral therapy measures in the HIV care cascade for women living with HIV in Canada. J. Acquir. Immune Defic. Syndr. 77, 144-153 (2018).

Muksin, R dkk. Stigma Masyarakat terhadap ODHA dengan HIV/AIDS. (2014).

Maharani, F. Faktor -Faktor Yang Berhubungan Dengan Stigma Terhadap Orang Dengan Hiv Dan Aids (Odha). J. Endur. 2, 158 (2017).

Meiyanto, S. Persepsi, nilai, dan sikap.UGM. (2015). Muksin, R. Faktor-Faktor yang Berhubungan dengan Stigma Guru terhadap Anak HIV Positif (Studi Pada Guru di Sekolah Mitra PKBI Daerah Jawa Tengah dalam Implementasi Pendidikan Kesehatan Reproduksi dan Seksual). 3, 230-237 (2015).

NAM. HIV, stigma \& discrimination 2015. Nam Aidsmap (2015).

Okumu, E. Corrigendum: Relationship between Human Immunodeficiency Virus (HIV) Knowledge, HIV-Related Stigma, and HIV Testing among Young Black Adults in a Southeastern City. Front. Public Heal. 5, 1-7 (2017).

Pasir, T., Utara, A. \& Sofia, R. Stigma Dan Diskriminasi Terhadap ODHA (Studi Pada Tenaga Kesehatan Di Puskesmas (Studies in Health Workers in the Tanah Pasir Health. 79-89

Priyoto.Teori Sikap \& Perilaku dalam Kesehatan. Numed: Yogyakarta.2014

RI, K. Profil Kesehatan Indonesia Tahun 2016. (2017).

Sastroasmoro, Sudigdo dan Sofyan Ismail. Dasar-Dasar Metodologi Penelitian Klinis Edisike-5. Jakarta: Sagung Seto. (2014)

Trianto, A. \& Werdani, Y. K. K. E. Pengaruh Pendidikan Kesehatan tentang HIV-AIDS melalui Buku Cerita terhadap Tingkat Pengetahuan, Sikap dan Daya Terima Remaja dalam Pencegahan HIV-AIDS di SMA. 3, 54-67 (2015).

Toth, S., A. York, J. \& DePinto, N. HIV stigma: perceptions from HIV-positive and HIV-negative patients in a community dental clinic. J. Dent. Res. Dent. Clin. Dent. Prospects 10, 263-269 (2016). 